\title{
PENGARUH TERAPI MUSIK SUARA ALAM TERHADAP KUALITAS TIDUR PASIEN KRITIS DI RUANG ICU RSU ROYAL PRIMA MEDAN TAHUN 2019
}

\author{
${ }^{1}$ Nur Iman Waruwu, ${ }^{2}$ Chrismis Novalinda Ginting, ${ }^{3}$ Devis Telaumbanua, ${ }^{4}$ Darwisman Amazihono, \\ ${ }^{5}$ Getzemane Putra Alfrain Laia \\ ${ }^{12345}$ Prodi S1-Keperawatan Fakultas Keperawatan Dan Kebidanan Universitas Prima Indonesia, Jl. Belanga \\ No. 1 simp. Ayahanda Medan \\ Email: ${ }^{1}$ waruwunuriman0503@gmail.com, ${ }^{2}$ chrismis@unprimdn.ac.id, ${ }^{3}$ Devistelaumbanua@gmail.com, \\ 4darwismazihono@gmail.com,5gethzemanelaia@gmail.com
}

\begin{abstract}
ABSTRAK
Musik suara alam merupakan suara alam seperti suara burung, gelombang laut, angin, air mengalir dll, sebagai terapi kesehatan yang mencapai hasil yang sangat memuaskan antara lain peningkatan kualitas tidur, kondisi fisik, mental bagi individu diberbagai tingkat umur. Tujuan dari penelitian ini mendeskripsikan perbedaan kualitas tidur pasien sebelum dan setelah pemberian terapi musik suara alam.Desain penelitian menggunakan teknik purposive sampling yang memiliki kriteria inklusi dan eksklusi. hasil uji normalitas Shapiro-wilk dimana data responden pada data pre-test memiliki nilai sig 0,002 <0,05, data post-test terdapat nilai sig 0,000 <0,05. Uji Wilcoxon Signed Rank Tes memiliki nilai Mean Rank pretest-posttest sebesar 6,00-0,00 dengan p-value 0,002 pada pasien kritis di ruang RSU Royal Prima Medan Tahun 2019.
\end{abstract}

Kata Kunci: Terapi Suara Alam, Kualitas Tidur.

\section{ABSTRACT}

Natural sound music is a natural sound of music such as the sound of birds, ocean waves, wind, running water, etc., as a health therapy that achieves very satisfying results including improving the quality of sleep, physical, mental conditions for individuals at various age levels. The purpose of this study is to describe differences in sleep quality of patients before and after the administration of natural sound music therapy. The study design uses a purposive sampling technique that has inclusion and exclusion criteria. Shapiro-Wilk normality test results where the respondent's data in the pre-test data has a sig value of $0.002<0.05$, the posttest data contained a sig value of $0.000<0.05$. Wilcoxon Signed Rank Test The test has a pretest-posttest mean rank of 6.00-0.00 with a p-value of 0.002 in critically ill patients in the Royal Prima General Hospital in 2019.

Keywords: Natural Sound Therapy, Sleep Quality.

\section{PENDAHULUAN}

Musik suara alam merupakan suara alam seperti suara burung, gelombang laut, angin, air mengalir dll, sebagai terapi kesehatan yang mencapai hasil yang sangat memuaskan antara lain peningkatan kualitas tidur, kondisi fisik, mental bagi individu diberbagai tingkat umur (Kurnia Wijayanti, dkk. 2016).

Musik terapi alam adalah salah satu terapi komplementer dalam penatalaksaan penderita yang mengalai gangguan tidur. Tindakan terapi musik memiliki pengaruh yang efektif dalam mengurangi gejala depresi pada penderita yang mengalami diagnose medis yang berbeda pada tingkat usia yang berbeda. Tidak adanya batasan bagi pengguna terapi ini, dan dapat diberikan pada semua penderita ganguan tidur (Dona. Mira,2010).

Musik suara alam adalah jenis musik yang baru akibat dari perkembangan teknologi, bentuk musik klasik dengan suara alam.komposisi suara yang dihasilkan oleh kejadian alam, seperti angin, burung, sungai, hujan dan. Gelombang laut.suara alam juga memiliki frekuensi yang berbeda, (Eka, Dhona, 2016).

Menurut E.O Wilson dalam bukunya biophilia mengemukakan bahwa manusia mempunyai ketertarikan dengan alam 
sehingga hubungan dengan alam mempunyai pengaruh teraupetik.(Lichtzin, dkk, 2010).

Tidur adalah salah satu kebutuhan dasar manusia yang bersifat fisiologis.tidur juga suatu kegiatan yang dilakukan tanpa sadar yang penuh. Tidur dipercaya mampu memulihkan energy karena tidur memberikan waktu untuk tubuh beristirahat sehingga system sraf dapat berelaksasi (Jenni, Dahl, 2008). Tidur adalah suatu gejasalah yang dialami oleh pasien kritis selama di rawat di ruangan Intensive Care Unit (ICU) pemberian terapi komplementer seperti terapi musik suara alam dapat memberikan manfaat yaitu meningkatkan relaksasi, memperbaiki kondisi fisik,psikis. Gangguan tidur pada pasien kritis terjadi dari fase awal pengobatan sampai akhir pemulihan setelah di ICU yang menjadi masalah serius selama lebih dua dekade. Tidur yang menganggu pada sistem kekebalan tubuh, neurologis, menghambat penyembuhan luka dan berpengaruh pada kondisi psikologis. Tidur memiliki peranan esensial bagi kualitas hidup sesorang (Kurnia.,dkk 2014).

Pasien yang dirawat di ICU sering merasakan kekurangan jam tidur, dengan berbagai macam gejalah termasuk pasien di ICU yang sering mengalami ganguan tidur yang sangat tinggi. (Jevon, Ewens, 2009).

Kualitas tidur dapat dikatakan sangat berperan bagi individu dalam pemulihan kesembuhan. kualitas tidur seseorang yang kurang baik dapat menimbulkan keseimbangan fisik dan mental . Depresi, cemas dan tidak konsentrasi merupakan tanda psikologis dari buruknya kualitas tidur, sedangkan dampak fisiologis nya berupa rasa lelah, penurunan aktivitas sehaihari,lambatnya penyembuhan luka, kekebalan tubuh menurun dan ketidak stabilan TTV (Bukit 2003 dalam Nurlela dkk,2009)

Menurut hasil penelitan Kurnia Wati dkk (2016) mengatakan bahwa terapi musik suara alam sebagai salah satu tindakan medis dan sesuai dengan SOP dapat diterapkan dalam perawatan pasien yang mengalami gangguan tidur.

Berdasarkan hasil penelitian Arina Merlianti dkk (2013) mengatakan bahwa
Terdapat pengaruh terapi musik dalam meningkatkan kualitas tidur.

Menurut hasil penelitan Eka Yulia Fitri dan Dhona Andhini mengatakan bahwa terdapat perberdaan yang signifikan kualitas tidur pre-test-post-test dalam mendengarkan terapi musik suara alam.karena efek dari terapi suara alam yang bersifat sedatif yang menyebabkan penurunan ketegangan, kecemasan, rasa nyeri, relaksasi, dan pola nafas sehingga pasien

Hasil survei awal yang di lakukan peneliti pada 9 april 2019 di ruangan ICU rumah sakit Royal Prima Medan ditemukan bahwa pasien kritis yang di rawat di ruang ICU 30 orang dan di temukan kritis.

Dari 20 pasien kritis tersebut 8 orang kritis berat, 8 orang kritis ringan dan 4 orang koma atau tidak sadarkan diri.pasien kritis diruangan ICU mengalami gangguan fisik dan psikis dalam menghadapi penyakit yang sedang dia alami. pasien kritis di ICU cenderung dengan ketakutan dan merasakan sakit serta gangguan tidur dan sangat membutuhkan terapi untuk membuat relaksasi. Berdasarkan hasil survey diatas maka peneliti tertarik untuk melakukan penelitian yang bertujuan untuk 'Terapi Musik Suara alam Terhadap Kualitas Tidur Pada Pasien Kritis di Ruang ICU'.

penelitian ini bertujuan untuk mengetahui distribusi frekuensi kualitas tidur berdasarkan jenis kelamin, umur, pada pasien kritis diruang ICU RSU Royal Prima Medan Tahun 2019.Untuk mengetahui kualitas tidur sebelum pemberian terapi musik suara alam pasien kritis di ruang ICU RSU Royal Prima Medan Tahun 2019. Untuk mengetahui kualitas tidur sesudah pemberian terapi musik suara alam pasien kritis di ruang ICU RSU Royal Prima Medan Tahun 2019. Untuk mengetahui pengaruh terapi musik suara alam terhadap kualitas tidur pada pasien kritis di ruang ICU RSU Royal Prima Medan Tahun 2019.

\section{METODE}

Jenis penelitian ini eksperiment Tempat Penelitian ini dilakukan pada dilakukan di 
ruang ICU RSU Royal Prima Medan Tahun 2019. Populasi dalam penelitan ini adalah pasien kritis yang di rawat di ruang ICU Rumah Sakit Royal Prima Medan sebanyak 30 orang. Sampel penelitian ini adalah 12 pasien yang dirawat diruang ICU RS Royal Prima.teknik Pengambilan sampel dalam penelitian menggunakan teknik purposive sampling.

Pengumpulan data menggunakan data primer yang diperoleh secara langsung, sehingga teknik pengumpulan data dalam penelitian ini adalah : observasi yang artinya teknik pengumpulan data kemudian mencatat gejala-gejala yang ditemukan dilapangan untuk melengkapi data yang diperlukan dalam permasalan penelitian (Margono, 2013).

Analisa data dilakukan untuk mengetahui hubungan antara variable independen dan variabel dependen menggunakan uji Wilcoxon pada program SPSS. Uji Wilcoxon dengan derajat kemaknaan Jika $\mathrm{p}<0,05$ maka Ho ditolak dan Ha diterima menujukkan bahwa terdapat hubungan antara variabel independen dan variabel dependen sementara jika $p>0,05$ maka Ho diterima Ha ditolak menunjukkan bahwa tidak terdapat hubungan antara variabel independen dan variabel dependen.

\section{HASIL}

\section{Analisa Univariat}

Tabel 1. Distribusi Frekuensi Karakteristik Responden Menurut Jenis Kelamin dan Umur Pada Pasien Kritis di Ruang ICU RSU Royal Prima Medan Tahun 2019

\begin{tabular}{lcc}
\hline $\begin{array}{l}\text { Karakteristik } \\
\text { Distribusi Responden }\end{array}$ & $\begin{array}{c}\text { Jumlah } \\
(\mathbf{n})\end{array}$ & $\begin{array}{c}\text { Persentase } \\
(\mathbf{\%})\end{array}$ \\
\hline Jenis Kelamin & & \\
\hline Laki-laki & 9 & 75,0 \\
\hline Perempuan & 3 & 25,0 \\
\hline Total & $\mathbf{1 2}$ & $\mathbf{1 0 0}$ \\
\hline Umur & & \\
\hline$<26$ Tahun & 1 & 8,3 \\
\hline 27-55 Tahun & 5 & 41,7 \\
\hline 60-70 Tahun & 4 & 33,3 \\
\hline 71-90 Tahun & 2 & 16,7 \\
\hline \multicolumn{1}{c}{ Total } & $\mathbf{1 2}$ & $\mathbf{1 0 0}$ \\
\hline \multicolumn{1}{c}{$\quad$}
\end{tabular}

Tabel 2. Distribusi Kualitas Tidur Responden Sebelum Diberikan Terapi Musik Suara Alam Pada Pasien Kritis di Ruang ICU RSU Royal Prima Medan Tahun 2019

\begin{tabular}{ccc}
\hline kualitas tidur & Jumlah (n) & Persentase (\%) \\
\hline Buruk & 10 & 83,3 \\
\hline Sedang & 1 & 8,3 \\
\hline Baik & 1 & 8,3 \\
\hline Total & $\mathbf{1 2}$ & $\mathbf{1 0 0}$ \\
\hline
\end{tabular}

Tabel 3. Distribusi Kualitas Tidur Responden Sesudah Diberikan Terapi Musik Suara Alam Pada Pasien Kritis di Ruang ICU RSU Royal Prima Medan Tahun 2019

\begin{tabular}{ccc}
\hline kualitas tidur & Jumlah (n) & Persentase (\%) \\
\hline Buruk & 0 & 0 \\
\hline Sedang & 2 & 16,7 \\
\hline Baik & 10 & 83,3 \\
\hline Total & $\mathbf{1 2}$ & $\mathbf{1 0 0}$ \\
\hline
\end{tabular}

\section{Analisa Bivariat}

Tabel 4. Pengaruh Terapi Musik Suara Alam Terhadap Kualitas Tidur Pada Pasien di Ruang ICU RSU Royal Prima Medan Tahun 2019

\begin{tabular}{lcc}
\hline Variabel & Mean Rank & $p$-value \\
\hline Kualitas Tidur & & \\
\hline Pre-Test & 0,000 & 0,002 \\
\hline Post -Test & 6,00 & \\
\hline
\end{tabular}

\section{PEMBAHASAN}

\section{Jenis Kelamin}

Berdasarkan pengumpulan data yang dilakukan, distribusi kualitas tidur berdasarkan jenis kelamin pada pasien di ruang ICU dimana mayoritas responden laki-laki 9 orang dengan persentasi $(75,0 \%)$ dan responden perempuan 3 orang dengan persentasi (25.o $\%)$. Responden laki-laki lebih banyak dari pada responden perempuan.

Setelah pemberian terapi musik suara alam, responden mengalami peningkatan kualitas tidur, berdasarkan penelitian perbedaan jenis kelamin tidak berpengaruh pada kualitas tidur pada pasien kritis tetapi tergantung pada pasien itu sendiri bagaimana dia bisa menerima terapi musik yang diberikan.

\section{Umur}


karakteristik usia responden pada pengumpulan data yang dilakukan maka di peroleh umur dengan rentang $<26$ tahun sebanyak 1 orang dengan persentasi $(8,3 \%)$, umur 25-55 sebanyak 5 orang dengan persentasi $(41,7 \%)$, umur $60-70$ sebanyak 4 orang dengan persentasi $(33,3 \%)$ dan yang umur 71-90 sebanyak 2 orang dengan persentasi $(16,7 \%)$.

Setelah pemberian terapi musik alam maka umur tidak berpengaruh pada kualitas tidur tergantung pada responden dalam menerima terapi musik dan pengalaman responden dalam mengenal musik serta ketertarikan responden pada musik.

Distribusi Kualitas Tidur Responden Sebelum Diberikan Terapi Musik Suara Alam Pada Pasien Kritis di Ruang ICU RSU Royal Prima Medan Tahun 2019.

Berdasarkan hasil penelitian distribusi frekuensi responden sebelum diberikan pengaruh terapi musik/suara alam terhadap kualitas tidur pasien mayoritas pasien mengalami kualitas tidur buruk hal ini dikarenakan pasien terlalu cemas pada penyakit yang dideritanya,pasien juga merasa terganggu dengan kebisingan yang ada di sekitarnya serta rasa sakit yang dideritanya,pasien juga merasa terganggu dengan alat medis yang menempel di tubuhnya, dan minoritas pasien mengalami kualitas tidur baik dan sedang.

Menurut hasil penelitian Eka Yulia (2016) mengatakan bahwa suara alarm, suara terhadap prorsedur perawatan kepada pasien lain yang sedang kritis, dan suara dari beberapa pengunjung dapat menyebabkan gangguan tidur.

Menurut asumsi peneliti bahwa pasien di ruang ICU mengalami ganggua tidur karena faktor lingkungan ,meliputi suara bising baik dari alarm alat-alat medis maupun suara percakapan petugas kesehatan, serta kecemasan yang di alami karena penyakit yang diderita pasien.

Distribusi Kualitas Tidur Responden Sesudah Diberikan Terapi Musik Suara
Alam Pada Pasien Kritis di Ruang ICU RSU Royal Prima Medan Tahun 2019

Berdasarkan hasil penelitian yang dilakukan distribusi frekuensi responden sesudah diberikan pengaruh terapi musik suara alam terhadap kualitas tidur pasien mayoritas pasien mengalami kualitas tidur baik sebanyak. hal ini disebabkan karena pasien merasa lebih rileks dan tenang saat mendengarkan music suara alam dan pasien merasa nberada di alam bebas dan tidak merasa berada di ruang perwatan ICU dan minoritas pasien mengalami kualitas tidur sedang. Menurut Eka yulia (2016) mengatakan bahwa adanya perbedaan rata-rata kualitas tidur pre-test dan post-test pemberian terapi music suara alam.

Menurut asumsi peneliti pasien setelah mendengarkan terapi musik suara alam responden lebih rileks dan pikirannya tenang serta mampu untuk tidur karna bisa mengalihkan rasa sakit dan melakukan relaksasi,pasien yang mendengarkan musik suara alam selama 30 menit tingkat stresnya berkurang dan lebih santai dengan menggunakan terapi music suara alam pasien tanpa tersadar akan tertidur.

Data Responden dan Pengaruh Pemberian Terapi Musik Suara Alam Terhadap Kualitas Tidur Pada Pasien di Ruang ICU RSU Royal Prima Medan Tahun 2019.

Berdasarkan hasil penelitian yang dilakukan menunjukan hasil uji Wilcoxon Signed Rank Tes memiliki nilai Mean Rank pretest-posttest sebesar 6,00-0,00 dengan $p$ value 0,002. Hasil menunjukkan adanya perbaikan kualitas tidur setelah pemberian musik suara alam dengan durasi 1x30 menit pada pagi hari pukul 08:00-08:30 dan 1x30 menit pada malam hari pada pukul 20:00$20: 30$

Mekanisme musik dapat mempengaruhi kualitas tidur pada manusia adalah : musik masuk melalui telinga, kemudian menggetarkan gendang telinga, menggungcang cairan ditelinga dalam serta menggetarkan sel-sel berambut didalam koklea untuk selanjutnya melalui syaraf koklearis menuju keotak. 
Hubungan musik dengan fungsi otak manusia yang dapat dapat mempengaruhi kualitas tidur yaitu jarak retikuler-talamus musik akan diterima langsung oleh thalamus, yaitu suatu bagian otak yang mengatur emosi, sensasi, dan perasaan, tanpa terlebih dahulu dicerna oleh bagian otak yang berpikir mengenai baik buruk maupun intelegensia, melalui hipotalamus mempengaruhi struktur basal "Forebrain" termasuk sistem limbic, hipotalamus merupakan pusat saraf otonom yang mengatur fungsi pernapasan, denyut jantung, tekanan darah, pergerakan otot usus, fungsi endokrin, memori, dll.

Melalui axon neuron secara difus mempersarafin neokorteks, dimana suatu rangsangan mencapai thalamus, maka secara otomatis pusat otak telah diinfasi.mengurangi aktivitas sistem syaraf simpatik, mengurangi kecemasan, jantung dan laju pernapasan serta memiliki efek positif pada tidur melelui relaksasi otak gangguan dari pikiran. Oleh karena itu musik alam dapat bermanfaat bagi pasien dengan gangguan tidur.Musik dipilih sebagai alternative karena musik dapat mebuat tubuh menghasil hormon beta-endorfin. Pada saat mendengar suara musik yang indah, hormon kebahagian (betaeendorfin) akan berprokduksi. Musik yang digunakan adalah musik suara alam yang sudah ditentukan selama 30 menit dipagi hari dan 30 menit dimalam hari selama enam hari dengan menggunakan pengeras suara.

\section{KESIMPULAN}

Menurut hasil penelitian mengenai pengaruh terapi musik suara alam terhadap kualitas tidur pada pasien kritis di ruang ICU RSU Royal Prima Medan Tahun 2019, maka ditarik kesimpulan sebagai berikut:

1. Distribusi karakteristik responden berdasarkan umur dengan mayoritas responden umur 27-55 dengan persentasi $41,7 \%$ (5 responden) dan minoritas < 26 tahun dengan persentasi $8,3 \% \quad$ (1 responden). Distribusi karakteristik responden berdasarkan jenis kelamin dengan mayoritas responden berjenis kelamin laki-laki dengan persentasi 75\% (9 responden) dan minoritas perempuan dengan persentasi $25 \%$ (3 responden).

2. Distribusi frekuensi responden sebelum diberikan pengaruh terapi musik suara alam terhadap kualitas tidur pasien mayoritas pasien mengalami kualitas tidur buruk.

3. Distribusi frekuensi responden sesudah diberikan pengaruh terapi musik suara alam terhadap kualitas tidur pasien mayoritas pasien mengalami kualitas tidur baik dan minoritas pasien mengalami kualitas tidur.

4. Terapi musik suara alam mampu meningkatkan kualitas tidur pasien kritis di ruang ICU.

\section{SARAN}

1. Diharapkan responden maupun keluarga mampu di ajak kerjasama dalam pemberian terapi dan dapat melaksanakan terapi yang dilakukan setelah selesai penelitian.

2. Diharapkan kepada pegawai untuk memberikan terapi musik kepada pasien dan melakukan sosialisasi pendidikan kesehatan tentang manfaat terapi musik suara alam kepada pasien yang mengalami gangguan tidur.

3. Bagi peneliti selanjutnya menjadi bahan referensi untuk melaksanakan penelitian pada pasien yang mengalami gangguan tidur dengan kasus yang berbeda dengan menggunakan musik suara alam.

\section{DAFTAR PUSTAKA}

Arina, M. (2013). Pengaruh Terapi Musik Terhadap Kualitas Tidur Penderita Insomnia Pada Lanjut Usia (Lansia) Di Panti Jompo Graha Kasih Bapa Kabupaten Raya. URL: jurnal.untan.ac.id.

Dody, S., S, F. Sri., E, Etika. (2013). Intervensi Terapi Musik Relaksasi Dan Suara Alam (Nature Sound) Terhadap Tingkat Nyeri Dan Kecemasan Pasien. URL: http://garuda.ristekdikti.go.id.

Epi, K. (2018). Pengembangan Instrumental Kualitas Tidur Dan Gangguan Tidur 
Dalam Penelitian. URL: https://www.researchgate.net/publication 1329000852.

Kurnia, W, J, Andrew., R, Nana. (2014). Musik Suara Alam Terhadap Peningkatan Kualitas Tidur Pada Pasien Kritis. URL: garuda.ristekdikti.go.id

Nasrul, S, Fakhrudin, A, Nurul Devi. (2017). Pengaruh terapi Musik Alam Terhadap Frekuensi Denyut Jantung Pada Pasien Selama Operasi Dengan Anestesi Spinal Di RSUD Pandan Arang Boyolali. URL: stikeskusumahusada.ac.id.

Nurdiansyah E. Tubagus. (2015). Pengaruh Terapi Musik Terhadap Respon Nyeri pada Pasien Dengan Post Operasi Di RSUD A. Dadi Tjokrodipo Kota Bandar Lampung. URL: ejurnal.poltekkestjk.ac.id.

Rodiya, N. Sri, A, Mas. (2017). Pengaruh Terapi Musik Instrumental Terhadap Insomnia Pada Lansia Di UPT Pelayanan Sosial Tresna Werdha Jombang. URL: jurnal.Stikespemkabjombang.ac.id.

Sri, U. \& P, Suryani Indra. (2018). Pengaruh Pemberian Terapi Musik Suara Alam Untuk Menurunkan Intensitas Rasa Nyeri Persalinan Kala Fase Aktif Di Puskesmas Toroh 1.

$U R L$ : akbidannurpurwodadi.ac.id.

Wijayanti W. dkk. (2016). Musik Suara Alam Terhadap Penurunan Kecemasan pada pasien Kritis. URL: Jurnal.unissula.ac.id.

Yulia, E. Eka., A, Dhona. (2016). Pengaruh Terapi Nature Sound Terhadap kualitas Tidur Pada Pasien Dengan Sindroma Koronaria Akut. URL: http://ejournal.unsri.ac.id. 